\title{
11. THE VOCAL-CHAMBER MUSIC RECITAL - THEORETICAL AND PRACTICAL ASPECTS OF AN INTERDISCIPLINARY APPROACH
}

\author{
Cezara Florentina Petrescu, \\ Alexandru Radu Petrescu ${ }^{121}$
}

\begin{abstract}
In a world of spectacle in which everything seems to have already been told, the vocal-chamber music recital is found in an identity crisis. The economic, social and cultural context in which it takes place is labile and determines the performers to ask themselves what is their position within the sctructures in which they function/operate. The purpose of the research is to identify and reevaluate links, configurations, structures and elements of a type of an aparently morally obsolet musical performance and marked by the passage of time. The originality of the thesis spans from its interdisciplinary character and from its multifaceted approach of the performative phenomenon.
\end{abstract}

Key words: Vocal-chamber music recital, performance, interdisciplinary approach

\section{Introduction}

An interdisciplinary approach to the lied recital starts/sprouts, in our opinion, from the double existence of the lied, as a musical and/or artistic work, and as a type of performance and cultural appurtenance. The dual nature of the lied was presented and argued by David Gramitt in his study, The circulation of the Lied: the double life of an artwork and a commodity ${ }^{122}$. He points out the double life of the lied throughout history as an artistic genre/artistic work and as goods of commerce, sellable on its specific market. He begins his argumentation with what he considers to be a truism, respectively the twofold nature of the lied, determined by the interaction between poetry and music, to then further go to the inclusion of the lied and other art forms in the context of capitalistic societies, the existence of the lied being tied to a certain phase. The author showcases that the lied's status as a time withstanding genre, from its origins ${ }^{123}$ to present days, was contested due to its status as a class of commodity too lasting/viable, which threatens its position as an art. The legitimacy of this affirmation is, maybe, validated in the western Europe; for other geographical areas, however, targeted scientific research are necessary. Gramitt localizes the lied borderline between high art and popular/folk music and showcases his preoccupation to probe, with prevalence, the nature of this exceedingly labile frontier and its fluctuations which, he says, are greater at the beginning of the $21^{\text {st }}$ century than the old

\footnotetext{
121 Associate Professor PhD., "George Enescu" National University of Arts from Iaşi, Romania, email: cezarapetrecu@yahoo.com, alrapet@yahoo.com

122 James Parsons (editor), The Cambridge Companion to the Lied, Cambridge University Press, 2004, pp. 301314.

123 Some authors take into consideration the year 1740, others take as a benchmark Schubert's creation, respectively his success with Gretchen am Spinrade on $19^{\text {th }}$ of October 1814, which meant the autonomizaton of the genre and its promotion to the rank of art, as affirmed by John Reed in his thesis on Schubert.
} 
limitations between high culture and mass culture which generated the wellknown controversies.

\section{Discussions}

The same author argues another duality of the lied, that of the imagined or already created variant by the author and its definitive form, which can be configured differently under the influence of the public's taste. The example presented is also Schubert who found success with lieds which had a pianistic introduction, a recipe adopted/embraced by the composer. Regarding the lied's status in the show, the play, many authors affirm its status of 'Cinderella', as opposed to opera, which had a comeback period in the attention of the public. In whichever/either posture we would find ourselves, as an interpret or a spectator, it is clear that the number of representations suffers a significant rarefying under the pressure of the economy, the public's taste - changing and dependent on massmedia manipulation - on the loss of tradition regarding a night of music, those Liederabends, which do not mobilize the interest of a large number of spectators and are paid modestly compared to a role in an opera or oratorio. Getting closer to the $21^{\text {st }}$ century, we bring in attention a few well known elements which help us build our argumentation.

Following the end of the Second World War, art, marked by the influence of trends and different 'isms`, showed a tighter and growing connection to society, even taking up the role of constructor of reality. An almost permanent process of auto-defining takes place parallel to the interdisciplinary character manifested ever so insistently alongside the destructive programs of the avant-garde. Under the influence of a routine spirit pertaining to the contemporary man, of the apparent commodity offered by the mass-media, of the temptation of humans to a simplified existence, the contemporary art became all the more dependent to a consumerist society to which it addresses itself, through its conditioning by the monetary element. Thusly, art is obligated to live up to the ideal of a safe financial investment, of profit, in the spirit of functionality and utility. From here the tendencies of contemporary artists to enlarge the area of every artistic manifestation's domain, following their own rules, liberty being claimed, sometimes ostentatiously so, bringing us to the situation ascertained by Thomas Munro: “[...] from our contemporaneous point of view, there are no precise limits/limitations to and art. Firstly, the domain expansion which will be covered by the notion of an art is an arbitrary problem that changes every once in a while. Secondly, the broadening of every notion pertaining to an art is slowly losing itself in those of other arts. Their defining contours overlap and merge imperceptibly, so that each has a margin of atypical, limitrophe cases which can very well qualify as either of several different arts" $" 124$.

The arts of simultaneity and those of succession develop relationships of

\footnotetext{
124 Thomas Munro, Artele şi relaţiile dintre ele, [Arts and connections between them], vol. II, Meridiane Publishing House, Bucureşti, 1981, p.228.
} 
inter-conditionality which give the contemporaneous artistic phenomenon its unitary character, despite the diversity of forms and methods of artistic manifestation. From this perspective, the evolution of the representations aligned itself to the contemporary musical and literary creation, as well as to the development of related arts, from which it borrowed means of expressions and scenic execution.

On the other hand, we observe that "in this moment pertaining to art's history, the global culture promoted by the mass-media becomes, by each day, the common, base tradition. We can see how, on the one hand, the modern impulses are combining themselves in a new way as well as, on the other hand, the experimental impulse combines itself with the commercial one [...] The conditions of art production have changed drastically in our time under the pressure of science and society" ${ }^{125}$. But, according to some researchers ${ }^{126}$, culture is viewed as a global process whose meanings are built from a social and historical point of view; literature and art only represent a part of "social communication"127, and the performance is an artistic deed, but also a moment of communication.

Following the evolutionary thread, voice and piano lied unravels itself as a depository genre of the amassments and transformation of the musical language, either as a preferential genre for composers, they themselves probing, configuring and then affirming their own stylistic beliefs, or as a scholastic genre which, once graduated, opens up new musical horizons.

\section{Results}

The lied repertoire constitutes a precious resource of musicians:

a) Didactical - for the forming of pianist and vocal interprets. We take into consideration both the knowledge and appropriation at a theoretical level of the diverse musical styles, of the ensemble of processes through which a composer materializes his artistic thought, but even more so the technical and expressive means through which an interpret can 'translate' the composer's thought. Of course, here the work strategy, the personal touch of a performer, the acceptable limits of the dogma etc. can vary. The contact to poetry can add more knowledge, but it also unravels an unknown universe for some.

b) For the 'personal development' of a musician, the lied is a 'tool', as, in our opinion, at any level of performance one might find himself, (re)visiting the lied is a therapy akin to Mozart's music.

c) Educative-Formative for the modeling of the public, due to the fact that, for the spectacle, it is no longer just an expression of life, of its subtlety and concreteness, but "constitutes a parenthesis of life, where to be means both more

\footnotetext{
${ }^{125}$ Dan Dediu, Radicalizare și guerilla. Teorii, ipoteze și proiecții muzicale, [Radicalization and guerilla. Theories, hypotheses, and music pojections], Muzicală Publishing House, Bucureşti, 2004, p. 268.

${ }^{126}$ Raymond Williams, in The long revolution, in line with the conceptions of the Centre for contemporary cultural studies, founded at Birmingham University in 1964.

${ }^{127}$ Jean Lohisse, Comunicarea. De la transmiterea mecanică la interacţiune, [Communication. From mechanic transmission to interaction], trans. Gabriela Scurtu Ilovan, Polirom, Publishing House, Iaşi, 2002, p. 164.
} 
and less than to live: more because, unlike the everyday universe, where the meaning of our actions are melted in their matter, without even being that matter, on the stage we play with meaning, to model and remodel our actions. From the public's perspective, theater (the spectacle, a. n.) is a lux of internalization represented without the risk of an attack at its intimate conditions of manifestation" 128 . Without debunking the perceptive method up to this point, we need a smooth change, in the way that it would enlarge the spectators' limits of accepting the novel. This thing can be realized through targeted reportorial policies, involving new horizons of attention, following a series of musical psychology research.

d) Performative - the immense repertoire which occasions (re)lectures, (re)interpretations, theatricalizations. We traverse the whole segment of resources to then come back, en large, over the issue of 'putting in scene' of a lied recital for voice and piano.

e) For interdisciplinary research - borderline approach, situated in between socio-humane concepts with specific references.

In order to to diversify and substantiate the interdisciplinary approach to the lied recital, it is useful to mention the perspectives from wich it is possible to analyze the vocal-chamber music recital.

1. The perspective of communication sciences - applying complex models on scenic communication, in the conditions in which the spectacles limits have extended, going as far as to interfere with the space of social reality.

Scenic communication integrates itself in the spectacle's universe, people agreeing to accept that those who make the show have something to say, to communicate, and those who come in the performance hall, the public, are open to receiving information, messages. Any scenic manifestation is a place of openness towards the world, of permanent creation, a place in which every spectator listens to other people and through them can see their own personality, culture, and discourse put in valor. In the contemporary period there's a growing importance granted to the role of the representation, the effects produced in society (opinions, ideas, behaviors), by the representation, by its "communication" towards the public.

Communication is a strategic means of development of an artistic action, in which sounds, words, images, and non-verbal elements combine, a specific method though which an artistic deed, the representation, is communicated. It's a traditional type of artistic communication, unlike that through mass-media, VHS or digital recording being types which, for now, innovative. It's a process which, through a simple, usual form, means the transmission of information (coded message) from the emitter to the receptor through the means of a canal. To define through this linear, unidirectional model means to apply the mathematical model

\footnotetext{
${ }^{128}$ Mihai Măniuţiu, Despre mască şi iluzie [About mask and illusion], Humanitas Publishing House, Bucureşti, 2007, p. 114.
} 
of Shannon and Weaver ${ }^{129}$ in which the fundamental element of the spectacle, what Jerzy Grotowski named "the proximity of the living organism" isn't entirely taken into consideration.

Just like in a spectacle/performance - an alive and unstable organism, permanently a subject of reconfiguration - scenic communication is nowadays considered a dynamic ensemble of elements which create relationships (of complementarity and/or bias) which unfold in a certain context (the organic theories of communication). As nowadays we use terms such as "political scene", "football-like show", "the actors" participating at an event, and we are oftentimes an implicit public of all these worldly "shows", we can appreciate that the model of scenic communication can be deformed to the point of becoming circular and complex. "We can say we find ourselves in communication, like a fish in the sea. The idea of transmission disappears, but that of contact surfaces $[\ldots\}<<$ the system creates complexity, maintains complexity, develops complexity>> (Morrin)" 130 . Referring to the lied recital, to the communication towards the public, in the spirit of Watzlawick's ideas we reiterate the notion that the sum that has to be taken into account, "The links which bind the elements of a system are so tight that modifying a single element will bring about the modification of every other elements of the whole system" 131 , a detectable situation in the case of scenic communication; if an element is changed, be it visual or audio, then a whole chain of transformations is produced and an inherent modification of what is communicated, of the senses etc.

2. Psychological perspective - small group

3. Managerial perspective - types of leadership. In the case of the voice-piano duo, it is interesting to determinate who assumes the role of the leader and which are the elements that favor the assuming of such a role.

On the other hand, lied repertoire also presents certain valences:

- In Europe, composers and works pertaining to the near past (20 $2{ }^{\text {th }}$ century) are brought back into attention - (further) enlarging the repertoire.

- The possibility of scenic representation, of 'staging' - a chance for renewal, to adequate the format to contemporary social through (re)theatricalization.

Josette Féral, critic and professor at the Superior theater school of the University of Quebec considers that theatricality ${ }^{132}$, although a subject of discussion

\footnotetext{
129 "Weaver [...] amplified the concepts and guided the works of his teacher to a more general theory of human behaviour: «the word communication will be used here in a broad sense, including al proceedings through which one spirit can influence another. This applies, not only to written or spoken discourse, but also to music, plastic arts, theatre, dance and, actually, the human behaviour in its wholeness» (C. Shannon, W. Weaver, 1975, p. 31)" apud Jean Lohisse, Comunicarea. De la transmiterea mecanică la interacţiune, [Communication. From mechanic transmission to interaction], trans. Gabriela Scurtu Ilovan, Ed. Polirom, Iaşi, 2002, p. 40.

130 Jean Lohisse, op. cit., p. 101.

131 P. Watzlawick, How real is real? Communication, désinformation, confusion, Random House, New-York, 1976; tr.fr. La réalité de la réalité , Edition de Seuil, Paris, 1978, p.123.

132 Josette Féral, Theatricality: The Specificity of Theatrical Language, in Josette Féral (editor) SubStance 98/99, Vol. 31, no. 2/3, Theatricality, 2002, pp. 94-108, published by the University of Wisconsin, Press, at http://www.brown.edu/Departments/German_Studies/media/Symposium/Texts.
} 
regarding the conditions of theatre production, does not exclusively pertain to it. The dilution of the borders between the types and genres of contemporary shows is due, in the author's opinion, the "emergence" of theatricality in their substance (dance-theatre, ambient theatre, instrumental theatre, etc.) or in the traditional genres (ballet, opera), this situation also leading to the difficulty to undertake the defining of theater's specific, an art which permanently redefines itself.

In the aforementioned study, Josette Féral argues that interpretation, governed in part by specific rules of the show as well as what diverse theatrical aesthetics presume or impose, creates a "theatrical framework" which can also be understood as a theatrical context. This is not a rigid finality, but a process generated by the expression of a subject in action, understood from the view of the relationships between it and the objects transformed in theatrical objects. The understanding of the spectators, acceptance of the interpretation and the proposed theatrical framing are in tight dependency with the culture and society. Thusly, theatricality seems a concept which cannot simply exist, but has to be "for someone", has to be perceived and accepted as a whole, because "it exists for the other" 133 .

Because theatricalization includes the textual, corporal and special dimensions of a representation, like the links created in between those, we realise that it can be configured and, even more so, understood with the performance phenomenon. Thusly, it can be found in its authentic formula only in theatre (a polyphonic system unlike the linear system of the spoken tongue, for example) where it is conceived under the aspect of "a significant polyphone open towards the spectator" 134 . But representations of every kind, due to their diversity and mobility, permanently redefine their own theatricality which, as John Gassner considers, has no form that is purely classic or traditional, unable to be found in a consistent, constant form.

\section{Conclusions}

Supporting the transformation of the recital, we list a number of arguments for theatricalization:

- The representative genres in musical spectacles specific to the $20^{\text {th }}$ century (chamber opera, rock opera, instrumental theater) generated influence, both from a musical and a performance viewpoint.

- music pervades theatrical representations and dance, but also in theater (actor's art, movement, décor, technique), which prompts the dilution or disbanding of boundaries between genres.

\footnotetext{
133 Josette Féral, „Performance and Theatricality: the subject demystified”, in Critical concepts in literary and cultural studies, vol. IV, Philip Auslander (editor), New-York, Routledge, 2003, p. 214.

${ }^{134}$ Bernard Dort, „Représentation émancipée”, in Actes Sud, col. "Le temps du théâtre », 1988, apud Jean Pierre Sarrazac, The Invention of theatricality, in Sud-Est, nr. 2/2007.
} 
- If dramatic literature is a type of artistic creation, different to the theater show, then the score of a lied cycle is fundamentally different to the artistic creation which is the lied recital.

- The world is a sum of performances which appear in different forms (information, propaganda, publicity, public consume); in other words, in this "staged" society, every each one of us at the same time and actor as well as public, willingly or implicitly, in the social show. The motif of "the world as a theater" seems to be revitalized, a motif George Banu says "it implies [...] the project of a show whose script, predetermined, forecasts both the distribution of roles attributed to every individual as well as control over its correct interpretation [...]. Theatrum mundi thusly represents a planetary spectacles from which nobody is excluded and in which every living being needs to integrate." 135

- The world presented by the spectacles is dominated by "goods", which develop quantitatively, in the detriment of quality;

- The technique of 'speculating', alongside the unilateral communication practiced by the mass-media facilitates the isolation of people;

- Theatricality is a contemporary concept in a world of (re)theatricalization;

- Lied is an 'international polyphony', so it contains theatricality which needs to be put fructified by the means of a type of representation which became outdated in the context of globalization, of exiting towards the social. Thusly, a 'reformatting' through the extension of the 'chamber's limits' and theatricalization is necessary. All it takes is the courage to be creative

\section{References}

1. Banu, George (2007). Scena supravegheată. De la Shakespeare la Genet [Surveilled scene. From Shakespeare to Genet], trans. Delia Voicu, Polirom/UNITEXT Publishing House, Iaşi/București

2. Dediu, Dan (2004). Radicalizare şi guerilla. Teorii, ipoteze şi proiecţii muzicale, [Radicalization and guerilla. Theories, hypotheses, and music pojections], Muzicală Publishing House, București

3. Dort, Bernard. „Représentation émancipée” în Actes Sud, col. „Le temps du théâtre" 1988

4. Féral, Josette. Theatricality: The Specificity of Theatrical Language, in: Josette Féral (editor) SubStance, 98/99, Vol. 31, No. 2/3, Theatricality, 2002, University of Wisconsin, Press la http://www.brown.edu/Departments/German_Studies/media/Symposium/Texts.

5. Féral, Josette. „Performance and Theatricality: the subject demystified”, in Critical concepts in literary and cultural studies, vol. IV, Philip Auslander (editor), New-York, Routledge, 2003

\footnotetext{
${ }^{135}$ George Banu, Scena supravegheată. De la Shakespeare la Genet [Surveilled scene. From Shakespeare to Genet], trans. Delia Voicu, Iaşi/Bucureşti, Polirom/UNITEXT Publishing House, 2007, p. 13.
} 
6. Lohisse, Jean (2002). Communication. From mechanic transmission to interaction, trans. Gabriela Scurtu Ilovan, Polirom Publishing House, Iaşi

7. Măniuţiu, Mihai (2007). Despre mască şi iluzie [About mask and illusion], Humanitas Publishing House, Bucureşti

8. Munro, Thomas (1981). Artele şi relaţiile dintre ele, [Arts and connections between them], vol. II, Meridiane Publishing House, Bucureşti

9. Parsons, James. (editor, 2004), The Cambridge Companion to the Lied, Cambridge University Press

10. Sarrazac, Jean Pierre. The Invention of theatricality, in Sud-Est, nr. 2/2007.

11. Watzlawick, Paul. How real is real? Communication, désinformation, confusion, Random House, New-York, 1976; tr.fr. La réalité de la réalité, Edition de Seuil, Paris, 1978 